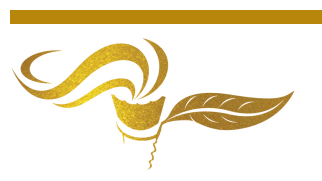

\title{
The Impact of the Covid-19 virus on Domestic Violence
}

\author{
Aygun Fuad gizi Gurbanova (student) ${ }^{1}$ and Paul Gibbs (advisor) ${ }^{2}$ \\ 1 Azerbaijan University, Social Work, Azerbaijan \\ 2 Emeritus Professor, Middlesex University, London, UK \\ * Correspondence: Email: p.gibbs@mdx.ac.uk
}

Received 27 November, 2020; Revised 3 February, 2021; Accepted 4 February, 2021

Available online 5 February, 2021 at www.atlas-journal.org, doi: 10.22545/2021/00153

\section{Short Letter}

Violence against women, especially by intimate partners, is one of the main problems throughout the world. Based on data from the World Health Organisation (WHO), as well as the Organization for Security and Co-operation in Europe (OSCE) almost $30 \%$ of women worldwide are sexually or physically abused by their partners at least once in their lifetime: up to $38 \%$ of women's deaths are caused by intimate partners, and only $11 \%$ of victims report the violence to the authorities. Women of any age are also exposed to various forms of violence in their homes by family members, usually referred to as 'domestic violence'. Crises and times of unrest have been linked to increased interpersonal violence, including incidents of violence against women and children (Fraser, 2020 [1]). Pandemics are no exception. In fact, the regional or global nature and associated fear and uncertainty of pandemics provide an enabling environment that may exacerbate or spark diverse forms of violence. Fraser, E. (2020 [1]). Peterman et al. (2020 [2]) document nine (direct and indirect) pathways linking pandemics and violence to women.

This paper presents a transdisciplinary approach to the problem of domestic female violence in Azerbaijan especially during COVID-19.

It discusses the literature in terms of transdisciplinarity and then, with this as a contextual basis, considers how Azerbaijan might act. The advantage of a transdisciplinary approach to gender violence is that it analyses the problem as well as its possible causes and considers the consequences from different points of view and hence, can put forward various proposals to diminish the gender violence rate. Flood and Pease (2009 [3]) in an Australian study found two clusters of factors associated with domestic violence and these were; gender and culture. These had an influence at multiple levels of the social order on attitudes regarding violence. Additional factors operate at individual, organizational, community, or societal levels in particular, although their influence may overlap across multiple levels. They proposed five ways of approaching the problem but none are possible as a disciplinary response. They require, although they don't call it as such, transdisciplinary problem solving. We have paraphrased them as:

1. The process of changing attitudes must be located within a project of changing familial, organizational, community and societal norms which support violence against women. 
2. Interventions must address the wider clusters of attitudes related to gender and sexuality which normalize and justify this violence.

3. Violence prevention interventions must be culturally appropriate.

4. Interventions aimed at attitudinal and cultural change must be accompanied by changes in structural relations and social practices if violence against women is to be prevented.

Such a framework might apply to Azerbaijan where the UN's Special Rapporteur on violence against women found that violence toward women was "underpinned by the persistence of patriarchal social norms, deeply-rooted gender stereotypes and misconceptions, as well as customary practices that are harmful to women. Azerbaijan has strong cultural traditions that place a high value on family and community" (2013 $[4])$.

Musso, Proietti and Reynolds (2012 [5]) investigate the international literature and find violence against women is a feature not only present in widely differing geocultural realities but also persistent and showing a polymorphic, transverse character related to male dominance which enables it (until now) to survive many social and legislative changes. Yet the research on this issue has remained disciplinary and their work on gender violence tends to remain discrete and fragmented. This disciplinary compartmentalization inhibits the understanding and possibility of coherent and consistent action, and approach which transdisciplinarity embraces. As Carew and Wickson, (2010 [6]) have stated, the study of gender violence necessarily transcends the academic and disciplinary boundaries traditionally utilized to understand and resolve research problems.

One transdisciplinary approach regarding violence against women was conducted by Adelman, Haldane, and Wies (2012 [7]). It was a study on violence against women on a USA campus in which they detailed how a transdisciplinary group reflecting a range of issues that might create a culture where such abuse might flourish or at least be resistant to confrontation. To achieve this requires the involvement of all those that create the salient cultural in which the problem is located and this culture perspective transcends the male and the female as the sole actors in any abuse. This widens the movements against gender violence from just within criminal justice and social services agencies, so as well as identifying the particular features and changing forms of this type of violence, the authors stress the adaptive, endemic and persistent character of this phenomenon and highlight its intimate and political matrix.

\subsection{Situation in Azerbaijan}

Publication of statistical indicators entitled "Women and men in Azerbaijan" by the State Statistics Committee of the Republic of Azerbaijan for 2018 shows that $76.0 \%$ of victims of domestic violence crimes are women. The Committee's report for 2019 notes the total number of victims of domestic violence is shown as 1,358, of which 1,038 are women, 12 are girls under 18. Thirty-seven female victims of domestic violence were killed, 831 were intentionally injured, eight were tortured, and two were threatened with death.

The following is a report of a small, anonymous survey in which 67 people attended a one-day survey to investigate the impact of the COVID-19 pandemic on domestic violence.

When asked if they had to spend more time at home during the "stay home" campaign than in previous periods, $95.52 \%$ of respondents answered "yes" and $49.25 \%$ of respondents answered "yes" to the question of whether spending more time with family members during quarantine caused family conflicts. When asked, $41.79 \%$ of respondents said that domestic violence is caused by both sexes, and $37.31 \%$ that it is men who generally inflict violence at home. When asked what type of violence was most common, $22.67 \%$ of respondents reported that it is harassment (checking and misappropriating personal belongings such as telephone, etc.); $22.9 \%$ of answers cited psychological violence (indifference, intimidation, disturbing); $16.28 \%$ responded by selecting economic violence (failure to meet basic material needs, misappropriation of income) and $12.21 \%$ answered by selecting physical violence (pushing, hitting, dragging). When respondents were asked which age group was most affected by domestic violence, $22.28 \%$ of them reported that people over 65 years of age are mostly vulnerable to domestic violence: for $17.10 \%$ these are people aged $31-45$, and $18.13 \%$ of them showed children aged 0-10 as victims of domestic violence during "stay home" campaigns. 
When asked what was done to protect the victim from domestic violence during quarantine, $52.13 \%$ of respondents said they could not leave the house; $29.79 \%$ of people said that they responded by resorting to various forms of violence as a way of self-defending. To the question of who protected the victim from the perpetrator, $60.56 \%$ chose the answer "nobody", while $36.62 \%$ of respondents asked other family members for help (son, daughter, father, mother, sister, brother, husband, wife, etc.). When asked what was used to protect the victim, $34 \%$ of respondents said they tried to make a phone call, $30 \%$ wrote a message and $30 \%$ tried to go to the doctor in order to avoid further disturbance. When asked who came home to protect the victim from the perpetrator, $85.96 \%$ of respondents answered "nobody", the other percentage is divided between parents, friends and relatives. These results hide the actual causes of the problem but can be read in a cultural way opening up concerns which can only be dealt with in ways that address a wide range of issues together and at a different level of reality.

To help understand the plight of women who suffer domestic violence in Azerbaijan we provide two narratives from two people involved in helping these vulnerable women. The first is a director of a shelter, the second a university academic.

Reflecting on these results, M. Zeynalova, director of the women's shelter "Clean World" under the auspices of Aid for Women Public Union, said that quarantine measures created conditions to cover up domestic violence. According to her, the facts from various countries about family members remaining indoors in quarantine creates conditions for an increase in domestic violence is also true for all of Azerbaijan. She confirms that during the quarantine period, women were placed in the shelter due to economic and physical violence. She said that during the quarantine period, most of the women victims of domestic violence who came with their children from both the regions and Baku (the capital), ran away from their abusive husbands and fathers. Police and local authorities tried to reconcile one of the couples, but to no avail. Some women, on the other hand, were unable to pay rent after losing jobs due to lockdown measures and had to seek refuge in the shelter. One of the reasons why women living in remote regions and facing domestic violence were unable to come to the shelter is that they are not aware of their right to call the police and ask them to help to escape the domestic violence during the quarantine. Many of them think that lockdown rules are applied without any exception, whatever happens people must stay indoors and the local police are not allowed to leave the region either, so instead they call the shelter and ask someone from the management to come to help them leave the house. Once women were made aware of their rights of state support during the pandemic and the role of the police to take them to a shelter, they were more able to escape the violence. It was suggested that local authorities should play a key role in this but there seems to be an indifference in local authorities during the quarantine period and the lack of active participation in the referral of women victims of violence.

The second person is a senior academic and Head of Department of Social Work of Azerbaijan University, Dr.Verdiyeva. She confirms that lockdown rules and restrictions of workplaces, the closure of entertainment venues, and even the closure of parks during the tighter quarantine period, forcing people to stay indoors, have increased domestic violence, commonly in its economic and physical forms. Thus, this kind of atmosphere at home may affect the emotional state of children, and lower their self-confidence and selfesteem. Extending the quarantine period to prevent the spread of the virus during the expected larger wave and the imposition of strict bans are expected to exacerbate domestic violence.

From both the survey and the reflections of two experts, several factors might be considered. These include gender inequality, legislation, women's economic dependence on men, lack of education about the issues of mutual respect, gender equality and equal distribution of gender roles in the family. Some of the possible solutions could be giving much more emphasis to school education: teaching respect, gender equality, sensitizing students to any manifestation of violence in general, and gender violence in particular. As far as the public health service is concerned, wider access to medical services, offering timely medical assistance to the victims of gender violence, as well as educating health workers, especially family doctors, to deal with the consequences of domestic and gender violence is required. In response to these challenges, a multi-layered National Action Plan to combat domestic violence for 2020-2023 was approved by the President of Azerbaijan. The plan was developed in accordance with the UN Convention on the Elimination of All Forms of Discrimination against Women (CEDAW) Convention. This action plan 
recognizes the complexity of the issue and will coordinate cooperation between government agencies, civil society institutions and international organizations in further improving the legislation, as well as ensuring the implementation of existing legislation to prevent domestic violence.

Author Contributions: Research team members equally contributed.

Funding: This research received no external funding.

Conflicts of Interest: The authors declares no conflict of interest.

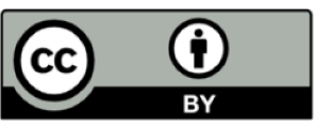

Copyright (C) 2021 by the authors. This is an open access article distributed under the Creative Commons Attribution License (https://creativecommons.org/licenses/by/4.0/), which permits unrestricted use, distribution, and reproduction in any medium, provided the original work is properly cited.

\section{References}

[1] Fraser, E. (2020). Impact of COVID-19 Pandemic on Violence against Women and Girls. Helpdesk Research Report No. 284. London, UK: VAWG Helpdesk.

[2] Peterman,A., Potts, a., O’Donnell, M.,Thompson, K.;. Shah, N.,Oertelt-Prigione, S. and van Gelder,N. (2020). Pandemics and Violence Against Women and Children. CGD Working Paper 528. Washington, DC: Center for Global Development. https://www.cgdev.org/publication/pandemics-and-violence-against-women-andchildren.

[3] Flood, M. and Pease, B (2009). Factors influencing attitudes to violence against women.Trauma, Violence, and Abuse, 10(2), pp. 125-142.

[4] Report of the Special Rapporteur on violence against women, its causes and consequences, on her mission to Azerbaijan (26 November-5 December 2013), (2014)https://undocs.org/A/HRC/26/38/Add.

[5] Musso, M. Proietti \& R. R. Reynolds (2020). Towards an integrated approach to violence against women: persistence, specificity and complexity, International Review of Sociology, 30:2, 249-278.

[6] Carew, A.L. and Wickson, F. (2010). The TD Wheel: a heuristic to shape, support and evaluate transdisciplinary research Futures, 42 (10) (2010), pp. 1146-1155.

[7] Adelman, M.; Haldane, H. and Wies, J.R. (2012). Mobilizing Culture as an Asset: A Transdisciplinary Effort to Rethink Gender Violence, Violence Against Women 18(6) 691 -700.

\section{Other Sources}

1. Awareness-raising on domestic violence and training materials on providing appropriate assistance to victims of domestic violence, Baku-2014.

2. Combating violence against women in the OSCE region. A reader on the situation in the region, good practices and the way forward updated edition, August 2017.

3. Providing social support services to victims of domestic violence. Baku 2017

4. Researching violence against women: a practical guide for researchers and activists, 2005

5. Women and men in Azerbaijan. State Statistics Committee of the Republic of Azerbaijan. 2018

6. Zeynalova M., Socio-economic aspects of domestic violence and ways to combat it. Baku-2015

7. https://president.az/articles/3535?locale $=$ en

8. https://www.stat.gov.az/source/crimes/

9. https://www.who.int/news-room/fact-sheets/detail/violence-against-women 


\section{About the Authors}

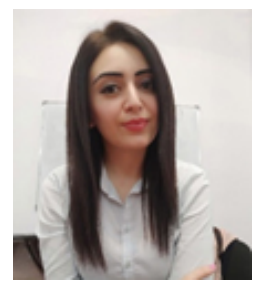

Aygun Fuad gizi Gurbanova is a second year PhD student in Social Work Department at Azerbaijan University studying under Professor Mais Nebi oglu Aliyev. Her doctoral research investigates social rehabilitation of women released from penitentiary institutions. She holds a master's degree in Social Work from Azerbaijan University. Her master's thesis was the social adaptation of women exposed to domestic violence, for which she conducted a research in a women's shelter. Between the years of 2019-2020 she conducted a study at the Republican Narcology Center in Azerbaijan on the link between domestic violence and the use of psychoactive substances by women. She currently teaches undergraduate students in social work at Odlar Yurdu University, Baku, Azerbaijan.

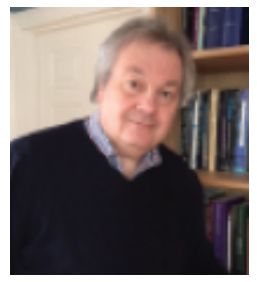

Dr. Paul Gibbs is Professor and Director of the Doctoral School, East European University. He is professor emeritus at Middlesex University, founder of the Centre for Education Research and Scholarship, and visiting professor at UTS Sydney and Azerbaijan university. His is a fellow of ATLAS as well as the Centre for Higher Education Policy, New College Oxford. He is an educator and researcher having taught notions of transdisciplinarity alongside social realism and Heideggerian hermeneutics. He has over 30 successful transdisciplinary professional doctorate students. He has published 20 books on topics ranging from the marketing of higher education to vocationalism and higher education and has published more than 100 academic articles. His particular approach to transdisciplinarity is informed by the works of Heidegger, Duns Scotus, and Deleuze and the theoretical insights of Basarab Nicolescu. He is also the series editor of SpringerBriefs on Key Thinkers in Education. 